Gulawentah: Jurnal Studi Sosial

Vol. 3, No. 1, Juni 2018, hal: 40-49

ISSN 2528-6293 (Print); ISSN 2528-6871 (Online)

Tersedia Online: http://e-journal.unipma.ac.id/index.php/gulawentah

\title{
Peningkatan Motivasi dan Prestasi Belajar IPS dengan Model Pembelajaran Tipe Think Pair Share pada Siswa Kelas VIII SMP Negeri 1 Takeran Magetan
}

\author{
Retno Dewati \\ SMP Negeri 1 Takeran, Ds. Jomblang Takeran Magetan 63323, Indonesia \\ Email: retnodewatidewati@yahoo.co.id
}

\begin{abstract}
Abstrak
Penelitian ini bertujuan untuk meningkatkan prestasi belajar IPS dengan menggunakan model picture and picture berbantuan metode menyanyi. Penelitian ini menggunakan penelitian tindakan kelas dengan 2 siklus. Subyek penelitian ini adalah siswa kelas VII A SMP Negeri 2 Saradan. Teknik pengumpulan data penelitian ini adlah observasi, tes dan dokumentasi. Hasil penelitian menunjukkan bahwa penggunaan model picture and picture berbantuan metode menyanyi dalam pembelajaran IPS dalam materi kondisi geografis dan penduduk dapat meningkatkan prestasi belajar Siswa kelas VII A di SMP Negeri 2 Saradan Madiun.Hal ini ditunjukkan pada siklus I sebanyak $46 \%$ tinggi, $36 \%$ sedang dan $18 \%$ rendah pada siklus II meningkat menjadi 22,72\% sangat tinggi, 72,78\% tinggi dan 4,5\% sedang. Peningkatan nilai rata-rata hasil belajar siswa juga mengalami peningkatan dari siklus I 77,95\% menjadi 82,05\% pada siklus ke II. Pada aspek afektif pada siklus I sebanyak 78,75\% menjadi 83,12\% pada siklus II.
\end{abstract}

Kata kunci: metode menyanyi; picture and picture; prestasi belajar

\section{Improving IPS Learning Prestation With Picture and Picture Model Assisted Method Singing In VII SMP Negeri 2 Saradan Madiun}

\begin{abstract}
This study aims to improve the learning achievement of IPS by using picture and picture model assisted singing method. This research uses classroom action research with 2 cycles. The subject of this research is the students of class VII A SMP Negeri 2 Saradan. Technique of collecting data of this research adlah observation, test and documentation. The results showed that the use of picture and picture model assisted singing method in IPS learning in the material geographical conditions and the population can improve student achievement class VII A in SMP Negeri 2 Saradan Madiun. This is shown in the first cycle of $46 \%$ high, 36\% moderate and $18 \%$ low in cycle II increased to $22.72 \%$ very high, $72.78 \%$ high and $4.5 \%$ moderate. The increase in the average score of student learning outcomes also increased from the first cycle of $77.95 \%$ to $82.05 \%$ in the second cycle. On the affective aspects of the first cycle as much as $78.75 \%$ to $83.12 \%$ in cycle II.
\end{abstract}

Keywords: learning achievement; picture and picture; singing method

DOI: 10.25273/gulawentah.v3i1.2225

Copyright $@ 2018$ Universitas PGRI Madiun

All rights reserved. 



\section{Pendahuluan}

Berdasarkan Undang- undang RI Nomor 20 tahu 2003 tentang Sikdiknas, Pendidikan nasional adalah pendidikan yang berdasarkan pancasila dan Undang-Undang Dasar Negara Republik Indonesia tahun 1945 yang berdasarkan pada nilai-nilai agama, kebudayaan nasional Indonesia dan tanggap terhadap tuntutan perubahan zaman. Dalam pembaharuan pendidikan yang mulai digalakkan beberapa puluh tahun yang lalu menyebabkan timbulnya berbagai usaha pemikiran diberbagai bidang pendidikan, seperti pembaharuan kurikulum, metode mengajar, administrasi pendidikan, media pendidikan, dan sistem supervisi. Adapun pembaharuan ini telah menimbulkan perubahan ukuran baik buruk perihal kegiatan pendidik, kegiatan peserta didik, suasana kelas dan banyak lagi hal lainnya.

Penentu arah tujuan pendidikan sangat dibutuhkan adanya kurikulum yang sesuai, yang pada akhirnya sebagai penentu kualitas lembaga pendidikan. Kurikulum dipahami sebagai rencana dan proses pelaksanaan pendidikan yang terstruktur secara formal dan tertulis dalam lingkungan pendidikan, sehingga kurikulum lebih dikenal dengan rencana pendidikan dan pengajaran atau program pendidikan. Kurikulum sebagai suatu rancangan dalam pendidikan memiliki posisi yang strategis, karena seluruh kegiatan pendidikan bermuara kepada kurikulum. Begitu pentingnya kurikulum sebagaimana sentra kegiatan pendidikan. Maka didalam penyusunannya memerlukan landasan atau fondasi yang kuat, melalui pemikiran dan penelitian secara mendalam. Pada dasarnya kurikulum merupakan suatu sistem yang terdiri dari beberapa komponen.

Komponen-komponen kurikulum suatu lembaga pendidikan dapat diidentifikasi dengan cara mengkaji buku kurikulum lembaga pendidikan itu, Dari buku kurikulum tersebut kita dapat mengetahui fungsi suatu komponen kurikulum terhadap kurikulum yang lain. Secara umum aplikasi kurikulum di kelas tidak terdapat perbedaan yaitu dititik beratkan pada pendidikan atau pendidik bidang studi dalam proses pembelajaran bagi anak didik. Namun realitanya banyak terjadi dalam proses pembelajaran di kelas, pendidik menemui permasalahan metode yang berimplikasi langsung maupun tidak langsung terhadap pencapaian tujuan pendidikan. Dalam rangka memecahkan permasalahan yang dihadapi pendidik, maka perlu adanya strategi pembelajaran. Strategi pembelajaran disini dimaksud adalah tindakan untuk mencapai tujuan yang dicitacitakan. Strategi pengajaran terdiri atas metode dan teknik atau prosedur yang menjamin peserta didik mencapai tujuan (Hamdani,2010:19). Peranan strategi pengajaran lebih penting apabila pendidik mengajar peserta didik yang berbeda dari segi kemampuan, pencapaian, kecenderungan, serta minat. Hal tersebut karena pendidik harus memikirkan strategi pengajaran yang mampu memenuhi keperluan peserta didik. Di sini, pendidik tidak saja harus menguasai berbagai kaidah mengajar, tetapi yang lebih penting adalah mengintergrasikan serta menyusun kaidah-kaidah itu untuk membentuk strategi pengajaran yang paling berkesan dalam belajar dan meningkatkan prestasi peserta didik.

Dilihat dari peranan pendidik sebagai seorang tenaga pendidik, pembimbing, pelatih, dan pemimpin yang dapat menciptakan suasana kelas yang menarik, aman, dan nyaman, keberadaanya di tengah-tengah peserta dapat mencairkan suasana kebekuan, kekakuan dan kejenuhan belajar yang terasa berat diterima oleh para peserta didik. Suasana kelas yang tidak kondusif akan berdampak negatif terhadap proses pembelajaran dan sulitnya tercapai tujuan pembelajaran, peserta didik akan merasa gelisah, resah, bosan, dan jenuh dan akhirnya menurunnya prestasi belajar peserta didik. 
Seperti halnya untuk pembelajaran IPS yang sangat komplek, karena dalam satu sisi tenaga pendidik IPS bukan asli dari jurusan IPS tetapi dari berbagai program studi ilmu-ilmu sosial seperti ekonomi, geografi, sejarah, sosiologi sehingga setiap pendidik mempunyai kemampuan berbeda-beda dalam menyampaikan materi pengajaran, yang kedua dalam menyampaikan materi pendidik masih sering menggunakan cara-cara tradisional yaitu dengan menggunakan metode ceramah saja tanpa inprovisasi dan tidak bervariasi. Sehingga peserta didik kurang termotifasi untuk belajar. Peserta didik mengangap pelajaran IPS adalah pelajaran yang monoton, hafalan, membosankan dan menjemukan.Selain dari pengamatan tersebut, juga hasil dari catatan dokumen terhadap hasil evaluasi belajar. Berdasarkan hasil pencatatan dokumen tersebut dapat disampaikan bahwa nilai rata-rata mata pelajaran IPS peserta didik kelas VII a SMP Negeri 2 Saradan Kecamatan Saradan Kabupaten Madiun di bawah Kriteria Ketuntasan Minimal (KKM). KKM sebagai salah satu prinsip penilaian ketuntasan yang ditetapkan 75, namun rata-rata nilai mata pelajaran IPS peserta didik SMP Negeri 2 Saradan hanya 60. Dari jumlah peserta didik sejumlah 22 atau $90 \%$ yang mencapai target KKM hanya 5 orang.

Untuk itu diperlukan suatu upaya menggunakan metode pembelajaran bervariasi agar prestasi belajar mata pelajaran IPS meningkat. Pendidik harus menguasai dan mampu menerapkan berbagai metode, model dan media yang tepat dan menciptakan proses pembelajaran yang kondusif sehingga dapat diperoleh prestasi belajar yang maksimal dan menghilangkan kejenuhan peserta didik dalam belajar serta belajar IPS adalah pelajaran yang menyenangkan dan dapat bermanfaat dalam kehidupan bermasyarakat. Hal ini sesuai dengan Peraturan Pemerintah No 32 tahun 2013 Pasal 77I ayat 1 yang menjelaskan bahwa bahan kajian Ilmu Pengetahuan Sosial, antara lain, ilmu bumi, sejarah, ekonomi, kesehatan, dan sebagainya dimaksudkan untuk mengembangkan pengetahuan, pemahaman, dan kemampuan analisis peserta didik terhadap kondisi social masyarakat.

Tidak sedikit model pembelajaran dan media pembelajaran yang dapat dijadikan sebagai alternatif untuk mengatasi masalah pembelajaran IPS di atas, salah satunya dengan menggunakan model pembelajaran Picture and Picture. Model ini merupakan salah satu dari beberapa model pembelajaran kontektual (Contextual Teaching and Learning atau CTL), Pembelajajaran CTL adalah konsep belajar yang membantu pendidik mengaitkan antara materi yang diajarkannya dengan situasi dunia nyata. Hal ini mendorong peserta didik membuat hubungan pengetahuan yang dimilikinya dengan penerapannya dalam kehidupan sehari- hari (Aqib,2013, 5). Dari teori diatas menunjukkan bahwa dengan mengunakan model Picture and Picture dapat meningkakan hasil belajar atau prestasi belajar peserta didik.

Model pembelajaran ini sebagaimana disebutkan Indien (2012) adalah suatu model pembelajaran dengan menggunakan media gambar seri. Dalam oprasionalnya gambar-gambar dipasangkan satu sama lain atau bisa jadi di urutkan menjadi urutan yang logis. Sedangkan menurut Agus (2011) Picture and Picture adalah teknik mengurutkan gambar. Teknik ini cukup menyenangkan untuk digunakan dalam mengulangi materi pembelajaran yang telah diberikan sebelumnya atau materi baru yang sedang diajarkan. Hal ini karena siswa dapat belajar sambil bermain. Model ini dapat digunakan dalam beberapa mata pelajaran, seperti Ilmu Pengetahuan Alam, Ilmu Pengetahuan Sosial, Matematika, dan Bahasa Indonesia. Teknik Picture and Picture juga cocok untuk semua kelas atau tingkatan.

Selain menggunakan model picture and picture penelitian ini juga menggunakan metode menyanyi dalam menunjang keberhasilan dalam proses belajar mengajar. Metode 
menyanyi adalah metode pembelajaran dimana dalam menyampaikan materi pembelajaran disampaikan dengan menyanyikan sebuah lagu atau beberapa lagu. Metode menyanyi menurut Alfajar (2012) adalah suatu cara dalam mengajar yang di dalamnya berisikan lagu-lagu yang berkesan dan menyenangkan.Sedangkan metode menyanyi menurut Poerwadarminta adalah mengeluarkan bunyi suara belagu dengan perkataan atau tidak melagukan dengan bernyanyi. Jadi sebuah metode menyanyi adalah bagian yang tak terpisahkan dari dunia anak-anak. Menyenandungkan lagu, apalagi yang berirama riang, sungguh merupakan kegiatan yang digandrunginya. Hal ini tidaklah mengherankan, karena lagu pada dasarnya adalah bentuk dari bahasa nada. Yaitu bentuk harmoni dari tinggi rendahnya suara. Pada insan-insan belia yang perbendaharaan bahasa masih cukup terbatas ini, bahasa nada justru lebih mudah mereka fahami.

Sedangkan yang membedakan penelitian ini dengan yang lainnya adalah dalam menyusun gambar (picture and picture) peserta didik yang lain menyanyikan sebuah lagu atau beberapa lagu untuk mengarahkan menyusun gambar (picture and picture) agar dalam menyusun gambar dapat terarah, dan tepat sasaran, yang diharapkan dengan model picture and picture dan metode menyanyi peserta didik tidak jenuh dan bersemangat didalam melakukan kegiatan pembelajaran di kelas sehingga dapat menigkatkan prestasi peserta didik. Berdasarkan hasil riset di atas menunjukkan adanya peningkatan, maka model picture and picture tersebut dengan metode menyanyi apakah dapat memingkatkan prestasi belajar peserta didik, maka perlu adanya penelitian.

\section{Metode Penelitian}

Penelitian ini menggunakan Penelitian Tindakan Kelas. Subjek penelitian ini adalah siswa kelas VIIA SMPN 2 saradan Kabupaten Madiun Tahun pelajaran 2016-2017 yang berjumlah 22 siswa meliputi 10 siswa perempuan dan 12 siswa laki-laki. Teknik pengumpulan data penelitian ini adalah: 1) Observasi yaitu peneliti menggunakan lembar observasi untuk aktivitas penelitian dan aktivitas siswa. 2) Tes yaitu peneliti menggunakan tes tulis yang merupakan tes yang dilakukan dengan cara siswa menjawab sejumlah item pertanyaan dengan cara ditulis.3) Teknik dokumentasi yaitu berupa foto hasil kegiatan pembelajaran dengan model picture and picture berbantuan metode menyanyi.

Analisis data dalam penelitian ini ditempuh melalui car merefleksikan hasil pengamatan dan hasil belajar selama proses pembelajaran yang berlangsung sesuai diklus dan tindakan yang dilakukan pada setiap siklus.dan untuk mengetahui ketuntaasan individu apabila siswa memperoleh daya serap 75\%. Dan secara klasikal dianggap tuntas apabila $80 \%$ dari jumlah siswa yang mencapai daya serap 75 . Sedangkan rumus untuk mengetahui ketuntasan belajar secara klasikal.

$\mathrm{KB}$ : ketuntasan belajar

$$
K B=\frac{N}{\eta} \times 100 \%
$$

$\mathrm{N}$ : banyaknya peserta didik yang mendapatkan nilai di atas 75

$\eta$ : banyaknya peserta didik yang mengikuti tes. 


\section{Hasil dan Pembahasan}

\section{Siklus 1}

Sebelum kegiatan pembelajaran IPS dengan metode picture and picture dan menyanyi, siswa kelas VII SMP Negeri Saradan dilakukan pretes. Hasil observasi tentang motivasi belajar dan pretesnya sebagaimana tercantum dalam tabel di bawah ini.

Tabel 1. Prestasi Belajar IPS Siswa Kelas VII SMP Negeri 2 Saradan Pada Prasiklus 1

\begin{tabular}{lc}
\multicolumn{1}{c}{ Hasil Belajar } & Nilai \\
\hline Nilai Rata-rata & 71,92 \\
\hline Nilai Tertinggi & 85 \\
\hline Nilai Terendah & 60 \\
\hline
\end{tabular}

Tabel 2. Motivasi Belajar IPS Siswa Kelas VII SMP Negeri 2 Saradan Pada Prasiklus 1

\begin{tabular}{lccc}
\hline \multirow{2}{*}{ Kriteria } & \multicolumn{2}{c}{ Hasil } \\
\cline { 3 - 4 } & & Jumlah Siswa & Persentase (\%) \\
\hline Sangat Tinggi & $81-100$ & 0 & 0 \\
\hline Tinggi & $61-80$ & 10 & 46 \\
\hline Sedang & $41-60$ & 8 & 36 \\
\hline Rendah & $21-40$ & 4 & 18 \\
\hline Sangat Rendah & $0-20$ & 0 & 0 \\
\hline
\end{tabular}

Setelah siswa melaksanakan kegiatan prasiklus, siswa melaksanakan kegiatan belajar pembelajaran. Dalam pembelajarannya, guru menggunakan pembelajaran kooperatif tipe picture and picture berbantuan metode menyanyi. Pada siklus 1 diperoleh hasil dari post tes mengalami perubahan. Hal ini bisa dilihat pada tabel 3.

Tabel 3. Nilai Prestasi Belajar IPS Siswa Kelas VII SMP Negeri 2 Saradan Pada Siklus 1

\begin{tabular}{clc}
\hline & \multicolumn{1}{c}{ Hasil Belajar } & Nilai \\
\hline 1 & Nilai Rata-rata & 77,95 \\
\hline 2 & Nilai Tertinggi & 85,00 \\
\hline 3 & Nilai Terendah & 70,00 \\
\hline 4 & Jumlah Siswa yang mendapat nilai $\geq 75$ & 17 \\
\hline 5 & Jumlah Siswa yang mendapat nilai $<75$ & 5 \\
\hline 6 & Persentase Ketuntasan & 77,27 \\
\hline 7 & Persentase Ketidaktuntasan & 22,73 \\
\hline
\end{tabular}

Dari data dalam tabel di atas menunjukkan bahwa nilai prestasi belajar IPS ratarat siswa 71,92, nilai tertinggi 85 dan terendah 60. Sedangkan data kuisioner motivasi awal siswa dapat dilihat di tabel di bawah ini. 
Tabel 4. Motivasi Belajar IPS Siswa Kelas VII SMP Negeri 2 Saradan Kelompok Kelas Bawah Pada Siklus 1

\begin{tabular}{lccc}
\hline \multirow{2}{*}{ Kriteria } & & \multicolumn{2}{c}{ Hasil } \\
\cline { 2 - 4 } & & Jumlah Siswa & Persentase $(\%)$ \\
\hline Sangat Tinggi & $81-100$ & 0 & 0 \\
\hline Tinggi & $61-80$ & 4 & 90,00 \\
\hline Sedang & $41-61$ & 1 & 10,00 \\
\hline Rendah & $21-40$ & 0 & 0 \\
\hline Sangat Rendah & $0-20$ & 0 & 0 \\
\hline
\end{tabular}

Tabel 5. $\quad$ Motivasi Belajar IPS Siswa Kelas VII SMP Negeri 2 Saradan Kelompok Kelas Atas Pada Siklus 1

\begin{tabular}{lccc}
\hline \multirow{2}{*}{ Kriteria } & \multicolumn{2}{c}{ Hasil } \\
\cline { 3 - 4 } & & Jumlah Siswa & Persentase (\%) \\
\hline Sangat Tinggi & $81-100$ & 5 & 29.41 \\
\hline Tinggi & $61-80$ & 12 & 70.59 \\
\hline Sedang & $41-61$ & 0 & 0 \\
\hline Rendah & $21-40$ & 0 & 0 \\
\hline Sangat Rendah & $0-20$ & 0 & 0 \\
\hline
\end{tabular}

Pada tahap Siklus II dilakukan perbaikan terhadap pelaksanakan Siklus I yaitu dilakukan pengamatan terhadap aktivitas yang dilakukan oleh siswa selama proses pembelajaran. Peneliti dibantu oleh teman sejawat untuk menjadi observer yang bertugas untuk mengobservasi kegiatan yang dilakukan oleh siswa selama mengikuti proses pembelajaran pada Siklus II. Hasil observasi ditulis di lembar observasi siswa dan observasi dilakukan pada setiap kelompok siswa. Pada siklus II ini dilakukan 2 kali pengamatan observasi sama dengan Siklus I, kemudian hasil observasi akan dirata-rata atau sebanyak jumlah pengamatan. Berikut ini disampaikan data motivasi dan prestasi belajar IPS pada siklus 2 .

Tabel 6. $\quad$ Motivasi Belajar IPS Siswa Kelas VII SMMP Negeri 2 Saradan Kelompok Kelas Bawah Pada Siklus 2

\begin{tabular}{cccccc}
\hline No & Nama & Pengamatan 1 & Pengamatan 2 & Rerata & Kategori \\
\hline 1 & Kelompok I & 75 & 80 & 77.50 & Tinggi \\
\hline 2 & Kelompok II & 80 & 85 & 82.50 & Tinggi \\
\hline 3 & Kelompok III & 85 & 90 & 87.50 & Tinggi \\
\hline 4 & Kelompok IV & 85 & 85 & 85.00 & Tinggi \\
\hline \multicolumn{7}{c}{ Persentase Kelompok Kategori Tinggi } & & $332 / 4 \times 100 \%=83.125$ \\
\hline
\end{tabular}

Tabel 7. $\quad$ Prestasi Belajar IPS Siswa Kelas VII SMP Negeri 2 Saradan Kelompok Kelas Bawah Pada Siklus 2

\begin{tabular}{clc}
\hline No. & \multicolumn{1}{c}{ Hasil Belajar } & Nilai \\
\hline 1 & Nilai Rata-rata & 82,05 \\
\hline 2 & Nilai Tertinggi & 90,00 \\
\hline 3 & Nilai Terendah & 75,00 \\
\hline 4 & Jumlah Siswa yang mendapat nilai $\geq 75$ & 22 \\
\hline
\end{tabular}




\begin{tabular}{clc}
\hline 5 & Jumlah Siswa yang mendapat nilai $\leq 75$ & 0 \\
\hline 6 & Persentase Ketuntasan & 100 \\
\hline 7 & Persentase Ketidaktuntasan & 0 \\
\hline
\end{tabular}

Pada Siklus II ini peneliti sudah melaksanakan upaya-upaya untuk memperbaiki proses pembelajaran pada Siklus I. Hasil belajar kognitif dan afektif siswa pada Siklus II ini mengalami peningkatan melebihi target yang ditentukan yaitu mencapai persentase ketuntasan $100 \%$. Pada ranah afektif dari hasil observasi yang dilakukan oleh observer juga mengalami peningkatan khususnya kelompok kelas bawah. Pembagian kelompok oleh peneliti yang dilakukan dengan cara mengelompokkan secara tersendiri siswa yang belum mencapai KKM pengayaan materi. Nilai terendah siswa pada post-tes I mengalami peningkatan dalam post-test II yaitu dari 70 menjadi 75. Jumlah siswa yang mencapai KKM juga mengalami peningkatan dari 17 orang siswa $(77,27 \%)$ menjadi 22 orang siswa $(100 \%)$. Sehingga membuat persentase siswa yang belum tuntas menurun drastis dari $22,73 \%$ menjadi $0 \%$.

Hasil belajar siswa dalam aspek afektif dapat dilihat dari hasil observasi yang dilakukan oleh observer. Observer bertugas untuk mengisi data di lembar observasi kelompok siswa. Anggota kelompok siswa dalam Siklus I dan Siklus II berbeda, pada Siklus II anggota kelompok telah dibagi oleh peneliti berdasarkan kemampuan akedemik siswa yang dilihat dari hasil post-test Siklus I. Dari data hasil observasi kelompok Siklus I akan dibandingkan dengan data hasil observasi kelompok pada Siklus II. Data yang dihasilkan akan dihitung dalam bentuk data kuantitatif. Berikut merupakan Tabel 4.10 hasil perhitungan dan pengelompokkan kategori dalam ranah afektif.

Tabel 8. Persentase Motivasi Belajar IPS Siswa Kelas VII SMP Negeri 2 Saran Pada Siklus I dan Siklus II

\begin{tabular}{clcc}
\hline No & Kategori & Siklus I & Siklus II \\
\hline 1 & Sangat Tinggi & $0 \%$ & $22,72 \%$ \\
\hline 2 & Tinggi & $78,75 \%$ & $72,78 \%$ \\
\hline 3 & Sedang & $21,25 \%$ & $4,5 \%$ \\
\hline 4 & Rendah & $0 \%$ & $0 \%$ \\
\hline
\end{tabular}

Berdasarkan data perhitungan observasi di atas, hasil belajar dalam aspek afektif dari Siklus I ke Siklus II mengalami peningkatan pada kategori sangat tinggi, yaitu rataratanya dari $0 \%$ menjadi $22,72 \%$. Ini membuktikan bahwa hasil belajar siswa kelas atas dalam ranah afektif pada Siklus II lebih baik dibandingkan dengan Siklus I karena menjadi siklus pengayaan materi bagi siswa yang mengalami kenaikan hasil post test yang dialami oleh 5 orang siswa.Sementara untuk kategori tinggi mengalami penurunan sebagai dampak dari 5 siswa tersebut. Namun demikian pada siklus II masih terdapat seorang siswa yang masih dalam kategori sedang dengan persentase $4,5 \%$. Hasil belajar siswa dalam aspek afektif pada Siklus I dan Siklus II adalah 95,5\%, ini memperlihatkan bahwa sikap siswa dalam mengikuti pembelajaran dikategorikan tinggi.

Sardiman (2014) menyatakan bahwa motivasi adalah serangkaian usaha untuk menyediakan kondisi-kondisi tertentu sehingga seseorang tersebut mau dan ingin melakukan sesuatu.Dapat disimpulkan bahwa motivasi adalah dorongan yang mengaktifkan, menyalurkan, dan mengarahkan sikap dan perilaku seseorang untuk mencapai tujuan yang diinginkan. Motivasi belajar ini dilihat dari lembar kuisioner yang telah diisi oleh siswa.Lembar kuisioner diberikan dua kali yaitu kuisioner motivasi awal yang diberikan sebelum pembelajaran Siklus I dan kuisionere akhir yang diberikan 
diakhir pembelajaran Siklus II. Kuisioner motivasi awal siswa pada siswa mengalami peningkatan dan mencapai indikator yang diinginkan. Terjadi peningkatan motivasi tinggi dari 56,66\% pada Siklus I menjadi sangat tinggi 22,72\% pada Siklus II diwakili 3 siswa. Peningkatan persentase motivasi ini menunjukkan bahwa siswa semakin termotivasi belajar dengan menggunakan pembelajaran Tipe Picture and Picture Berbantu Metode Menyanyi.

Selain dari data lembar kuisioner, hasil yang memperlihatkan bahwa siswa termotivasi dengan pembelajaran Tipe Picture and Picture Berbantu Metode Menyanyi adalah pada saat berdiskusi kelompok. Pada saat melakukan pembelajaran Tipe Picture and Picture Berbantu Metode Menyanyi, siswa terlihat sangat antusias dan bersemangat, baik itu dalam menempel kartu konsep, melengkapi LKS dan menjawab pertanyaan dari kelompok lain. Pada saat menjawab pertanyaan di LKS, siswa dengan segera dapat mengerjakannya karena masih mengingat materi yang dipelajari menggunak pembelajaran Tipe Picture and Picture Berbantu Metode Menyanyi.Hal ini dapat dikatakan bahwa pembelajaran Tipe Picture and Picture Berbantu Metode Menyanyi dapat meningkatkan motivasi siswa dalam pembelajaran dan membantu siswa untuk dapat lebih mengingat pelajaran yang sudah dipelajari.

Menurut Suprijono (2009) Picture and Picture adalah salah satu metode pembelajaran yang menggunakan gambar dalam bentuk potongan - potongan untuk kemudian dipasangkan serta diurutkan menjadi gambar yang utuh.Pemasangan dan pengurutan gambar dapat dilakukan secara perorangan maupun dengan kelompok. Pemasangan dan pengurutan gambar dilakukan secara kelompok akan meningkatkan interaksi sosial siswa. Dalam kelompok, siswa akan saling membantu dan berdiskusi satu sama lain. Gambar yang dimaksud dalam penelitian ini adalah gambar yang berkaitan dengan materi pembelajaran.Pembelajaran Tipe Picture and Picture ini memiliki banyak kelebihan sehingga membuat siswa termotivasi dengan pembelajaran tersebut, diantaranya adalah suasana pembelajaran menjadi lebih menyenangkan karena siswa Siswa lebih cepat menangkap materi yang diajarkan karena guru menunjukkan gambargambar sesuai dengan materi yang dipelajari.

Berdasarkan data hasil belajar kognitif pada Tabel 4.9 maka perkembangan kognitif siswa pada Siklus I dan Siklus II dapat digambarkan dalam grafik berikut ini. Berdasarkan gambar 4.12 di atas, hasil post-test siklus I dan post-test siklus II mengalami peningkatan. Dari semula rata-ratanya adalah $77,27 \%$ meningkat 5,37\% menjadi $82,64 \%$. Sedangkan jumlah siswa yang mencapai KKM dari 77,27\% meningkat sebanyak 22,73\% menjadi $100 \%$. Pada Siklus II ini tidak ada satupun siswa yang tidak tuntas. Pada Siklus I, hasil post-test siswa mencapai rata-rata kelas yaitu 77,27\%. Dari hasil yang diperoleh dalam Siklus I tersebut dapat dikatakan belum mencapai indikator yang ditetapkan oleh peneliti, dimana indikator yang ingin dicapai adalah 75 poin untuk rata-rata kelas. Namun untuk rata-rata persentase siswa yang mencapai nilai KKM adalah 77,27\%, dari hasil tersebut dikatakan sudah mencapai indikator yang ditetapkan oleh peneliti namun ada 5 siswa yang masih dibawah KKM. Karena indikator yang ingin dicapai untuk ketuntasan siswa dalam mencapai nilai KKM adalah 75\%.Ini memperlihatkan bahwa persentase siswa yang tuntas pada Siklus I sudah mencapai target yang ditentukan terlepas dari 5 siswa yang masih dibawah KKM, sehingga peneliti memperbaiki pembelajaran pada Siklus II untuk meningkatkan hasil belajar kognitif siswa dibawah KKM dan pengayaan materi bagi siswa yang sudah mencapai nilai KKM.

Penelitian Siklus II nilai rata-rata post-test siswa adalah 81,66 dan ketuntasan belajar siswa yang mencapai KKM adalah $100 \%$. Penelitian pada Siklus II ini dapat 
dikatakan berhasil karena hasil post-test pada Siklus II mengalami peningkatan dan telah mencapai target yang diinginkan. Hasil kognitif siswa pada Siklus II mengalami peningkatan, ini dapat dibuktikan pada nilai rata-rata kelas maupun dari persentase siswa yang mencapai KKM.Peningkatan hasil belajar kognitif siswa juga dipengaruhi oleh suasana pembelajaran yang lebih kondusif dibandingkan dengan Siklus I, tidak hanya suasana pembelajaran yang mendukung.

Faktor lain yang mempengaruhi hasil belajar aspek kognitif ini seperti yang dikemukakan oleh Nasution dalam Djamarah (2006) yaitu sarana dan fasilitas yang mendukung dalam pembelajaran, kondisi panca indra, lingkungan alami, lingkungan sosial budaya, minat siswa dalam mengikuti pembelajaran tersebut dan yang terakhir kecerdasan siswa yang dimiliki. Pada Siklus II, peneliti memperbaiki proses pembelajaran yang terjadi di Siklus I, yaitu dengan cara membagi kelompok secara rata berdasarkan hasil kognitif siswa Siklus I. Kemudian dalam Siklus II, kelompok belajar siswa menjadi rata antara siswa yang memiliki hasil belajar tinggi dengan siswa yang memiliki hasil belajar rendah, dengan demikian dalam kelompok belajar di Siklus II semua siswa dalam kelompok akan terlibat aktif dan siswa yang tidak tahu akan menjadi tahu.

Selain itu, ada beberapa hal yang memperlihatkan bahwa siswa menyukai pembelajaran Tipe Picture and Picture Berbantu Metode Menyanyi dengan menggunakan kartu gambar dan kartu konsep tersebut, yaitu pada saat diakhir pembelajaran peneliti meminta siswa untuk berefleksi. Pada tahap ini, peneliti bertanya kepada 3 siswa yang memiliki hasil belajar rendah, sedang, dan tinggi.Peneliti bertanya tentang bagaimana tanggapan siswa terhadap pembelajaran Tipe Picture and Picture Berbantu Metode Menyanyi.Untuk siswa yang memiliki hasil belajar rendah dan dibawah rata-rata mengemukakan bahwa dengan menggunakan pembelajaran Tipe Picture and Picture Berbantu Metode Menyanyi membuat mereka lebih aktif dan lebih mengingat tentang materi yang diajarkan.Dari pernyataan yang mereka kemukakan dan dari data yang ada membuktikan bahwa penggunaan pembelajaran Tipe Picture and Picture Berbantu Metode Menyanyi dalam pembelajaran berhasil meningkatkan hasil belajar siswa. Selain itu, karena alat yang digunakan selama pembelajaran sangat menarik, sehingga membuat siswa juga tidak bosan dalam melakukan proses pembelajaran.

Dapat dilihat bahwa hasil analisis perhitungan rata-rata aspek afektif dari Siklus I ke Siklus II mengalami peningkatan dari 78,75\% menjadi 92,36\%. Hal ini membuktikan bahwa hasil belajar afektif siswa dikategorikan baik.Hasil afektif siswa dari Siklus I sudah dikategorikan baik, hal ini ditunjukkan pada saat siswa bersama dengan kelompok sangat antusias dan bersemangat mengikuti pembelajaran menggunakan Picture and Picture Berbantu Metode Menyanyi.Pada saat pembelajaran, siswa terlihat sangat aktif dan serius, ini juga disebabkan oleh karena pembelajaran Picture and Picture yang menyenangkan dan membuat semua siswa terlibat aktif dalam proses pembelajaran. Adapun indikator aspek afektif yang harus diperhatikan dalam penilaian ini adalah semangat siswa dalam mengikuti pembelajaran, perhatian siswa dalam melaksanakan pembelajaran (memperhatikan atau tidak memperhatikan), kedisiplinan siswa dalam mengumpulkan tugas, partisipasi siswa dan percaya diri siswa dalam mengemukakan pendapat.Dari aspek-aspek tersebut, siswa sudah melengkapi penelitian aspek yang sudah ditentukan sehingga hasil dari Siklus I dan hasil siklus II dapat dikatakan baik dan mengalami peningkatan selama proses pembelajaran berlangsung.

Berdasarkan hasil peningkatan rata-rata observasi pada aspek afektif, menunjukkan bahwa pembelajaran Tipe Picture and Picture Berbantu Metode Menyanyie dapat 
meningkatkan aspek afektif siswa dalam pembelajaran. Karena proses pembelajaran tersebut seperti bermain sambil belajar sehingga tidak membuat siswa merasa bosan dengan pembelajaran.

Ada beberapa masalah yang timbul pada proses pembelajaran Siklus I, diantaranya adalah kurang bisa mengkondisikan kelas, hal ini dikarenakan siswa yang terlalu aktif untuk bertanya sehingga membuat suasana kelas menjadi sangat ribut dan waktu melebihi yang ditargetkan. Oleh sebab itu, pada proses pembelajaran Siklus II permasalahan tersebut diperbaiki yaitu dengan cara peneliti lebih tegas dalam mengkondisikan suasana kelas. Di Siklus II peneliti juga telah membagi kelompok siswa secara bervariasi dalam kemampuan berpikir yang dilihat dari hasil post-test Siklus I, maka dari itu proses pembelajaran pada siklus II dapat berjalan dengan baik. Sehingga siswa memiliki sikap afektif yang baik dan motivasi yang tinggi pad a saat pembelajaran diskusi kelompok berlangsung.

\section{Kesimpulan}

Prestasi belajar dan motivasi belajar IPSsiswa kelas VII SMP Negeri 2 Saradan dapat ditingkatkan dengan menggunakan model picture and picture berbantuan metode menyanyi. Hal tersebut ditunjukkan pada siklus I sebanyak $46 \%$ tinggi, $36 \%$ sedang dan $18 \%$ rendah pada siklus II meningkat menjadi $22,72 \%$ sangat tinggi, $72,78 \%$ tinggi dan 4,5\% sedang. Peningkatan nilai rata-rata hasil belajar siswa juga mengalami peningkatan dari siklus I 77,95\% menjadi $82,05 \%$ pada siklus ke II. Pada aspek afektif pada siklus I sebanyak $78,75 \%$ menjadi $83,12 \%$ pada siklus II.

\section{Daftar Pustaka}

Akhmadi, A. (2016). Penelitian Tindakan Kelas (Panduan Praktis Pengembangan Profesi Guru dan Konselor). Sidoarjo: Nizamia Learning Center.

Alfajar, L.H. (2014). Upaya Pengembangan Pendidikan Karakter di Sekolah Dasar Negeri Sosrowijayan. Skripsi. Yogyakarta: FKIP PGSD UNY.. 2014. Upaya Pengembangan Pendidikan Karakter di Sekolah Dasar Negeri Sosrowijayan. Skripsi. Yogyakarta: FKIP PGSD UNY.

Aqib, Z. (2015). Model-Model, Media dan Strategi Pembelajaran Kontekstual(Inovatif). Bandung: Yrama Widya.

Hamdani, H. (2011). Strategi Belajar Mengajar. Bandung: Pustaka Sertia.

Hamdani, H. (2013). Pengembangan Sistem Pendidikan di Indonesia. Bandung: CV Pustaka Mulia.

Hujair Ah Sanaky, 2013.Media Pembelajaran Interaktif- Inovatif. Yogjakarta: Kaukaba Dipantara.

Indien. (2012). http://007indien.blogspot.com/2012/06/model-pembelajaran-pictureand-picture.html.

Sardiman, A.M., (2014). Interaksi dan Motivasi Belajar Mengajar. Jakarta: Rajawali Pers.

Suprijono, A. (20019). Cooperative Learning Teori \& Aplikasi PAIKEM. Yogyakarta: Pustaka Pelajar 